\title{
Effect of aquapuncture on postoperative analgesia after ovariohysterectomy in dogs
}

\section{Efeito da aquapuntura na analgesia pós-operativa após ováriohisterectomia em cadelas}

\author{
Stelio Pacca Loureiro Luna ${ }^{1 *}$; Nareshkumar Hasmukhlal Kelawala ${ }^{2}$; \\ Alfredo Feio da Maia Lima3; Erja Elina Saarto4; Flavia Corte Restitutti ${ }^{4}$; \\ Nuno Emanuel de Oliveira Figueiredo da Silva ${ }^{5}$
}

\begin{abstract}
Aquapuncture (AqP) consists of a water or saline solution injection into acupoints. This study aimed to evaluate the effect of aquapuncture on post-operative analgesia in bitches submitted to elective ovariohysterectomy (OHE). The study was prospective, randomised, and blinded for pain assessment. Sixteen dogs were randomly distributed in two groups of eight animals each. All animals were sedated with $0.05 \mathrm{mg} \mathrm{kg}^{-1}$ of acepromazine intramuscularly (IM), 30 minutes prior to induction of anaesthesia with propofol and maintenance with isoflurane. Eight animals underwent bilateral acupoint injection with $0.1 \mathrm{ml}$ of $0.9 \%$ saline (AqP) at Gall Bladder 34, Stomach 36, Liver 3 and Spleen 6 acupoints 15 minutes after sedation. Pain score was investigated after $0.5,1,2,5,8$ and 24 hours post-operatively and was compared with a control untreated group of eight animals. Morphine, at $0.5 \mathrm{mg} \mathrm{kg}^{-1} \mathrm{IM}$, was administered when the numerical rating scale was above $33 \%$ of the maximum value, in order to control post-operative pain in both groups. There were no differences in cardiorespiratory variables and pain and sedation scores between the groups. Seven (87.5\%) animals from the control group required rescue analgesia at the first two postoperative hours and five (62.5\%) animals treated with AqP required rescue analgesia, however, only one (12.5\%) animal was treated at the first two hours and the remaining animals were treated from 5 hours after surgery. Aquapuncture produced residual analgesia up to $5 \mathrm{~h}$ after surgery and may be an option for post-operative analgesia in bitches undergoing OHE, providing that pain is assessed and rescue analgesia administered if necessary.
\end{abstract}

Key words: Acupuncture, pain, surgery, morphine

\section{Resumo}

A aquapuntura (AqP) é uma técnica que consiste na injeção de solução fisiológica ou água destilada em pontos de acupuntura. Este estudo teve como objetivo avaliar o efeito da AqP na analgesia pós-

\footnotetext{
${ }^{1}$ Prof. Dr., Dept ${ }^{\circ}$ de Cirurgia e Anestesiologia Veterinária, Faculdade de Medicina Veterinária e Zootecnia, FMVZ, UNESP, Universidade Estadual Paulista, Campus de Botucatu, SP, Brasil. E-mail: stelio@fmvz.unesp.br

2 Prof. Department of Surgery \& Radiology, College of Veterinary Science \& A.H. Gujarat Agricultural University, Anand Gujarat, India. E-mail: drkelawala_anand@yahoo.com

${ }_{3}$ Prof. Dr. Colaborador, Dept ${ }^{\circ}$ de Cirurgia e Anestesiologia Veterinária, FMVZ, UNESP, Campus de Botucatu, SP. Brasil. E-mail: alfciru@gmail.com

${ }^{4}$ Researchers, Department of Equine and Small Animal Medicine, Faculty of Veterinary Medicine, University of Helsinki, Finland. E-mail: erja.saarto@fimnet.fi; flavia.restitutti@helsinki.fi

${ }_{5}^{5}$ Discente do Curso de Mestrado em Medicina Veterinária, Dept ${ }^{\circ}$ de Cirurgia e Anestesiologia Veterinária, FMVZ, UNESP, Campus de Botucatu, SP, Brasil. E-mail: emmanunno@gmail.com

* Author for correspondence
} 
operatória em cadelas submetidas à ovariohisterectomia eletiva (OHE). O estudo foi prospectivo, aleatório e "cego" para avaliação da dor. Dezesseis cadelas foram distribuídas aleatoriamente em dois grupos de oito animais cada. Todos os animais foram sedados com $0.05 \mathrm{mg} \mathrm{kg}^{-1}$ de acepromazina por via intramuscular (IM), 30 minutos antes da indução à anestesia com propofol e manutenção com isoflurano. Oito animais foram submetidos à injeção bilateral com $0,1 \mathrm{~mL}$ de solução salina $0,9 \%$ (AqP) nos acupontos Vesícula Biliar 34, Estômago 36, Fígado 3 e Baço 6, 15 minutos após a sedação. A dor foi avaliada $0,5,1,2,5,8$ e 24 horas após a cirurgia e comparada com um grupo controle não tratado, de oito animais. O resgaste analgésico foi realizado com $0,5 \mathrm{mg} \mathrm{kg}^{-1}$ de morfina IM quando o escore de dor foi superior a 33\% do valor máximo em ambos os grupos. Não houve diferenças nas variáveis cardiorrespiratórias e escores de dor e de sedação entre os grupos. Sete $(87,5 \%)$ animais do grupo controle necessitaram analgesia de resgate nas duas primeiras horas de pós-operatório e cinco $(62,5 \%)$ animais tratados com AqP necessitaram analgesia de resgate, no entanto, tratou-se apenas um $(12,5 \%)$ animal nas primeiras duas horas e tratou-se os demais apenas a partir de 5 horas após a cirurgia. A AqP produziu analgesia residual de até 5 horas após a cirurgia e pode ser uma opção para analgesia pós-operatória em cadelas submetidas à OHE, desde que a dor seja monitorada e o resgate analgésico administrado se necessário.

Palavras-chave: Acupuntura, dor, cirurgia, morfina

\section{Introduction}

Ovariohysterectomy (OHE) is a relatively standardised source of moderate soft tissue pain in dogs (HANSEN, 2003). Acupuncture (AP) is the insertion of needles in specific cutaneous locations of the body, known as acupoints (LUNA et al., 2008), which have a lower electric resistance and a greater sensitivity to pressure. This technique of Traditional Chinese Medicine (TCM) is used for the treatment or prevention of several diseases (HABACHER et al., 2006). Several studies have been carried out to demonstrate the beneficial effects of AP (ALVARENGA et al., 1998; CLARK, 2011; JOAQUIM et al., 2008, 2010; LUNA, 2000; LUNA; TAYLOR, 1998).

A systematic review reported that acupuncture and related techniques may be a useful adjunct analgesic for acute postoperative pain (SUN et al., 2008). One of the most studied effect of AP is analgesia, produced by the stimulation of certain acupoints (CASSU et al., 2008; LUNA, 2002; TEIXEIRA et al., 2013). Several acupoint combinations can be used to produce analgesia. The most important ones are Gall Bladder 34 (GB34), Spleen 6 (SP6), Stomach 36 (ST36) and Liver 3 (LIV3) (CASSU et al., 2008; TEIXEIRA et al., 2013; WRIGHT; MCGRATH, 1981).
The analgesia produced by AP is similar to that produced by opioids (LUNA, 2002; GAKIYA et al., 2011; GROPPETTI et al., 2011). Abdominal surgery have been successfully performed under AP analgesia in dogs (LOPES et al., 1998; STILL, 1987; WRIGHT; MCGRATH, 1981), but this technique has more frequently been used to treat postoperative pain in dogs and humans (DI MARTINO; LUNA, 2010; LIN et al., 2002; PIGNATON et al., 2007; SOUSA et al., 2012; TEIXEIRA et al., 2013).

Acupoint injection is one of the methods used for AP treatment and some advantages may be attributed to this technique, such as a shorter period of restraint required and the use of ordinary material. Aquapuncture (AqP) or water puncture is the injection of saline or distilled water into acupoints. The goal is to provide a prolonged mechanical stimulus in the acupoint. Pharmacopuncture is the injection of subclinical doses of drugs in acupoints, and has been adopted with successful results. Some authors claim that this technique enhances the mechanical acupuncture stimulus period and produces similar effects as conventional doses of drugs (LUNA et al., 2008; SOUSA et al., 2012; TAFFAREL et al., 2012).

The use of acupoint injection, instead of conventional AP or electroacupuncture (EA), 
might facilitate the procedure, as it is not necessary to maintain the needles in the acupoints and no electrical current would be required, avoiding the risk of electrolysis, electrophoresis, residual ionisation, change in local $\mathrm{pH}$, and electrical burning (KLIDE; GAYNOR, 2001). Additionally, the acupoints may be stimulated simultaneously, uniformly and for a longer period, considering the maintenance of the stimuli after the removal of the needles. Aquapuncture also does not require expensive EA equipment and the presence of needles or electrodes which might disturb the activities of the surgeon. Toxicity or adverse reactions (MATHEWS, 2000) are important concerns when conventional analgesics are used, particularly morphine due to respiratory depression, emesis and histamine release. Aquapuncture might be a good option to evade these effects.

The hypothesis of this study is that AqP is effective for postoperative analgesia in dogs submitted to OHE. The aim of this study was to evaluate the postoperative analgesic effects of preoperative AqP in dogs undergoing elective OHE.

\section{Methods}

This study was prospective, randomised, and blinded for pain assessment and it was approved by the Institutional Ethical Committee for the Use of Animals.

\section{Animals}

Sixteen non-pregnant bitches of different breeds, with age of $6 \pm 1.4$ years and weighing $7.6 \pm 5.3$ $\mathrm{kg}$ were used. Complete clinical examinations of all animals were carried out to ensure apparent clinical health status. The animals were registered for elective OHE at the institution. Dogs were sedated with $0.05 \mathrm{mg} \mathrm{kg}^{-1}$ of acepromazine 6 , 30 minutes prior to the induction of anaesthesia with $5 \mathrm{mg} \mathrm{kg}^{-1}$

\footnotetext{
6 Acepran (2 mg/mL), Univer, São Paulo, Brasil
}

of propofol $1^{7}$, and maintenance of anaesthesia with isoflurane ${ }^{8}$ using a circle system ${ }^{9}$.

\section{Treatment groups}

The dogs were randomly distributed into two groups of eight animals each: control (CG) and treatment (TG). Animals of TG were subjected to bilateral injection of $0.1 \mathrm{~mL}$ saline solution $(0.9 \%$ $\mathrm{NaCl}$ ) at GB34, ST36, LIV3 and SP6 acupoints 15 minutes after sedation and 15 minutes prior to induction of anaesthesia.

The Tsu-san-li (ST36) acupoint is located 3 cun distal to the lateral head of the fibula. The acupoint Yangling-chuan (GB34) is located at the proximal end of the interosseous space between the tibia and fibula, the acupoint San-yin-chiao (SP6) is located 3 cun proximal to the medial malleolus and the Taichong (LIV3) is located on the medial side of the pelvic limb, proximal to the metatarsophalangeal joint between the second and third metatarsal bones (XIE; VANESSA, 2002).

Elective OHE was performed by the same experienced surgeon in all animals, using a standard minimally invasive technique. The animals were assessed for heart rate, respiration rate, blood pressure and rectal temperature during surgery. Whenever heart rate or systolic arterial blood pressure was above $20 \%$ of pre surgical values, $2 \mu \mathrm{g}$ of fentanyl was administered intra-operatively IV.

\section{Pain assessment}

Time to extubation postoperatively, head raising and standing position were recorded. The animals were maintained in kennels where pain was assessed at $0.5,1,2,5,8$ and 24 hours postoperatively. Pain was evaluated by a blind investigator, using an adapted variable count numerical descriptive scale

\footnotetext{
7 Propovan $(10 \mathrm{mg} / \mathrm{mL})$, Cristália, Itapira, São Paulo, Brasil

8 Isoforine $(1 \mathrm{~mL} / \mathrm{mL})$ Cristália, Itapira, São Paulo, Brasil

9 Takaoka Electronica 1822, Multiagente modular 1410, K. Takaoka, São Paulo, Brasil
} 
(FIRTH; HALDANE, 1999; PIBAROT et al., 1997) along with visual analogue scale (VAS) for sedation assessment. When the total pain score at any time for $24 \mathrm{hr}$ postoperatively was correspondent to $33 \%$ of the total score, the animals were treated with 0.5 $\mathrm{mg} \mathrm{kg}{ }^{-1}$ of morphine ${ }^{5} \mathrm{IM}$. The same anaesthetist and acupuncturist treated all patients; and the same blinded evaluator, qualified in assessing pain in dogs, performed all pain assessments.

\section{Statistical analysis}

Considering that data were normally distributed after using the Shapiro-Wilk test, the statistical analysis was carried out by one way ANOVA (Analysis of Variance) followed by Tukey's test to investigate differences in time. Differences between groups, at each time point, were investigated by two-way ANOVA followed by Tukey's test. Differences in the number of rescue analgesia used were investigated by Fisher's Exact test. Statistical analysis was performed using Jandel Sigmastat version 2.0 software. $A p<0.05$ value was considered significant.

\section{Results}

There were no significant differences between groups with regards to body weight (CG: $9.9 \pm$ 2.7; TG: $9.1 \pm 2.2 \mathrm{~kg}, \mathrm{p}=0.54$ ), dose of propofol for induction of anaesthesia (CG: $5 \pm 0.99 \mathrm{mg} / \mathrm{kg}$; TG: $5 \pm 1.36 \mathrm{mg} / \mathrm{kg}-\mathrm{p}>0.99$ ), duration of surgery (CG: $8 \pm 2$ minutes; TG: $9 \pm 3$ minutes, $\mathrm{p}=0.48$ ) and physiological parameters. Mean heart rate, respiratory rate and systolic arterial blood pressure remained within normal values between 80 and 120 beats/minute, 18 and 33 breaths/minutes and 106 and $133 \mathrm{mmHg}$ during anaesthesia in both groups. Temperature decreased from $39.5^{\circ} \mathrm{C} \pm 0.7$, before sedation, to $36.8^{\circ} \mathrm{C} \pm 1$ at the end of anaesthesia (45 minute after induction of anaesthesia) in the $\mathrm{CG}$ and from $39.4^{\circ} \mathrm{C} \pm 0.7$ to $37.4^{\circ} \mathrm{C} \pm 1.1$ at the same time points in the $\mathrm{TG}$, no significant difference was present between groups $(p=0.19$ at the last moment). ${ }^{10}$

Recovery from anaesthesia was smooth, however, head shaking and vocalisation was observed in three $(37.5 \%)$ out of eight animals from the CG and two (25\%) out of eight animals treated with AqP. Salivation was observed in two $(25 \%)$ animals in the control group, which was not observed in any of the animals of the treatment group. Two (25\%) animals from the control group showed mild to moderate salivation during and after surgery. There was no significant difference for the time to extubation, head raising and standing time between groups (Table 1). There was no difference in pain score and VAS for sedation either between the groups or within time points for each group (Figure 1).

Table 1. Time in minutes to extubation, to the first movement of the head and standing time after OHE in untreated bitches $(\mathrm{CG}-\mathrm{n}=8)$ and in bitches submitted to AqP preoperatively $(\mathrm{TG}-\mathrm{n}=8)$.

\begin{tabular}{lccc}
\hline Group & $\begin{array}{c}\text { Time to } \\
\text { extubation }\end{array}$ & $\begin{array}{c}\text { First head } \\
\text { movement }\end{array}$ & $\begin{array}{c}\text { Standing } \\
\text { time }\end{array}$ \\
\hline Control & $7 \pm 3$ & $14 \pm 4$ & $33 \pm 11$ \\
AqP & $9 \pm 4$ & $13 \pm 4$ & $28 \pm 5$ \\
\hline p value & $\mathrm{p}=0.32$ & $\mathrm{p}=0.79$ & $\mathrm{p}=0.30$ \\
\hline
\end{tabular}

${ }^{10}$ Dimorf (10 mg/mL), Cristália, Itapira, São Paulo, Brasil. 
Figure 1. Mean $\pm_{-}$SD of pain score (A) and VAS (B) for sedation after OHE in $\mathrm{CG}$ - untreated bitches $(\mathrm{n}=8)$ and in TG - bitches submitted to AqP preoperatively ( $\mathrm{n}=8$ ) (ANOVA, followed by Tukey's test).
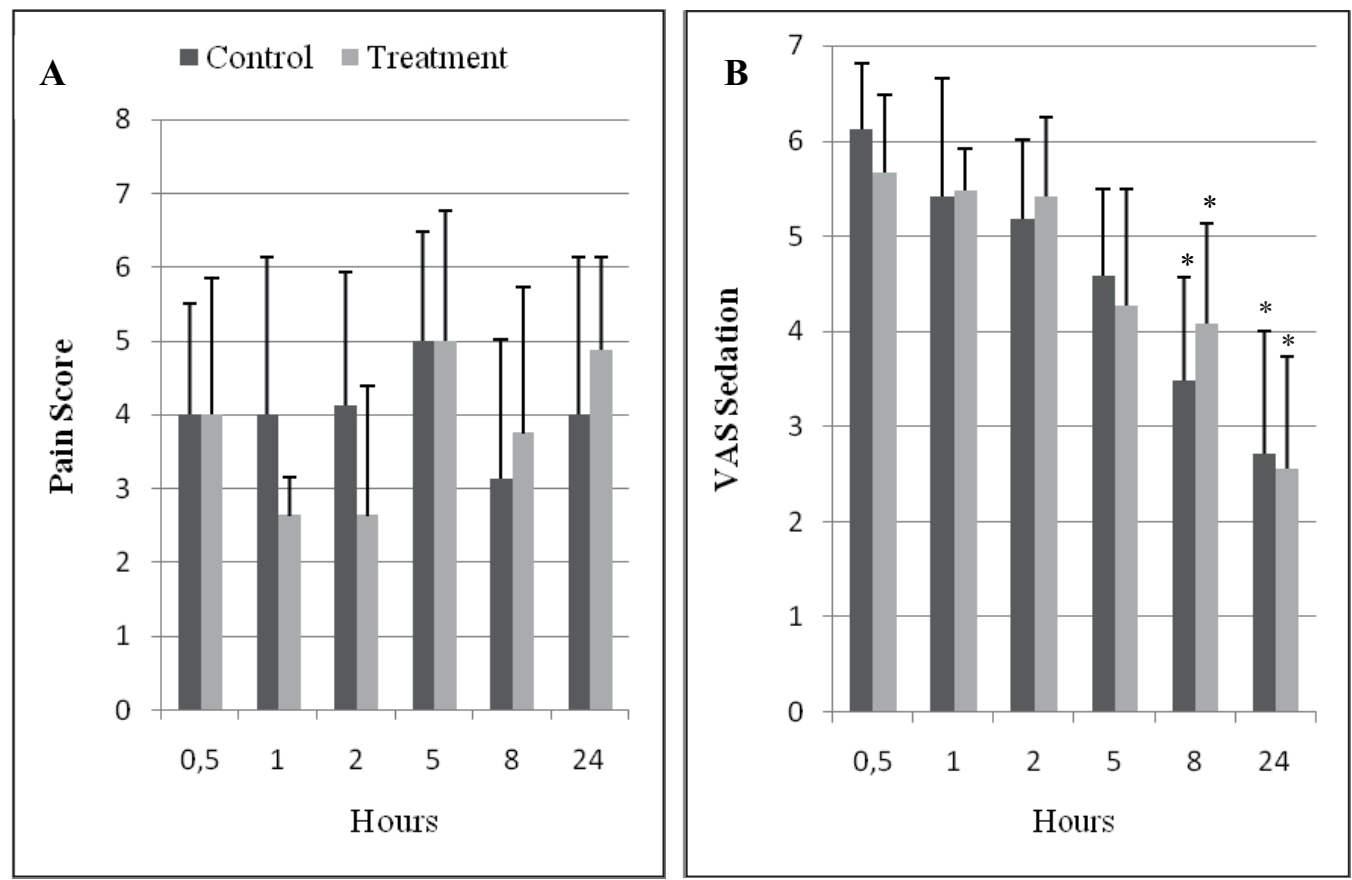

* indicates differences at 8 and $24 \mathrm{~h}$ postoperatively when compared to the first $(0,5)$ moment in each group

SD - Significant Difference; VAS, Visual Analogue Scale; ANOVA, Analysis Of Variance;

OHE, Ovariohysterectomy; AqP, Aquapuncture.

Morphine was administered seven and five times in animals from the control and AqP groups, respectively. In the $\mathrm{CG}$, three dogs (37.5\%) received morphine once and two dogs $(25 \%)$ received morphine twice. In the AqP group, three dogs $(37.5 \%)$ received morphine once and one dog
$(12.5 \%)$ received morphine twice. All dogs from the $\mathrm{CG}$ received morphine at the first two hours postoperatively. In $\mathrm{TG}$, only one dog (12.5\%) needed supplementary analgesia for the first two hours after surgery $(\mathrm{p}=0.01)$ and the others at 5,8 and 24 hours after surgery (Table 2).

Table 2. Time of administration of morphine (rescue analgesia) after OHE in untreated bitches $(n=8)$ and in bitches submitted to AqP preoperatively $(\mathrm{n}=8)$.

\begin{tabular}{ccccc}
\hline & \multicolumn{2}{c}{ Control group } & \multicolumn{2}{c}{ Acupuncture group } \\
\hline Dogs & $1^{\text {st }}$ analgesic rescue & $2^{\text {nd }}$ analgesic rescue & $1^{\text {st }}$ analgesic rescue & $2^{\text {nd }}$ analgesic rescue \\
\hline 1 & $30 \mathrm{~min}$ & - & $480 \mathrm{~min}$ & - \\
2 & $120 \mathrm{~min}$ & - & $300 \mathrm{~min}$ & - \\
3 & $120 \mathrm{~min}$ & - & $60 \mathrm{~min}$ & $24 \mathrm{~h}$ \\
4 & $60 \mathrm{~min}$ & $24 \mathrm{~h}$ & $24 \mathrm{~h}$ & - \\
5 & $60 \mathrm{~min}$ & $24 \mathrm{~h}$ & - & - \\
\hline
\end{tabular}




\section{Discussion}

Aquapuncture produced longer postoperative analgesia when compared to saline in bitches undergoing OHE. In this study, saline was injected to stimulate the acupoint instead of AP or EA. Acupoint injection was well tolerated among the animals and according to the authors' experience, this type of stimulation was more practical in performance and more comfortable for the animal, when compared to either AP or EA, mainly because it was not necessary to restrain the dogs for maintenance of needles in place during the acupuncture section, which usually lasts approximately 30 minutes.

Ovariohysterectomy modifies behaviour in dogs for up to 24 hours after surgery (HARDIE, 1997; FOX et al., 2000; SHIH et al., 2008) and is considered a moderately painful procedure.

The point selection and the mode of stimulation are important for the outcome of AP for postoperative pain relief (CASSU et al., 2008; CHERNYAK; SESSLER, 2005, KOTANI et al., 2001). The acupoint selection in this study was based on previous successful reports of AP-induced analgesia (GAKIYA et al., 2011; LOPES et al., 1998; SOUSA et al., 2012; STILL, 1987; TEIXEIRA et al., 2013; WRIGHT; MCGRATH, 1981). Aquapuncture was performed bilaterally because the time to effect, the intensity and duration of analgesia is intensified when compared to unilateral stimulation (CASSU et al., 2008). In TCM, ST36 is the master point for the abdomen and gastrointestinal tract, SP6 is the master point for the caudal abdomen and genitourinary region, GB34 is the influential point for tendons and ligaments, and LIV3 is Shu-stream point (earth) and Yuan-source point, used to guarantee a smooth flow of Qi, a very commonly used point in painful conditions, gastrointestinal and urogenital disorders (XIE; VANESSA, 2002).

The ST36, SP6, GB34 and LIV3 are the most commonly used acupoints for surgical analgesia in dogs (O'BOYLE; VAJDA, 1975; STILL, 1987; WRIGHT; MCGRATH, 1981), however, the analgesic effects of acupuncture may be unpredictable (CAO, 2002), as EA at ST36 and SP6 or ST36 and GB34 produced sufficient analgesia for abdominal incision and gentle manipulation of the viscera in only $25 \%$ and $89 \%$ of bitches, respectively (WRIGHT; MCGRATH, 1981). Otherwise the use of acupuncture as an adjuvant of anaesthesia is a potential application of acupuncture. EA performed in SP 6 or ST36 reduces minimal alveolar concentration of halothane (TSENG et al., 1981) and isoflurane (SKARDA; MUIR, 2003) by $20 \%$ in dogs. Limb and abdominal thermal and mechanical anti-nociception and post-incisional anti-hyperalgesia have been reported after EA in ST36 and SP6 in dogs (CASSU et al., 2008) and rats (OLIVEIRA; PRADO, 2000).

A major part of studies investigating the effect of AP have been related to pain assessment and the possible mechanisms behind the acupuncture analgesic effects have been reported elsewhere (CAO, 2002; HE, 1987; LIN; CHEN, 2008; MCLENNAN et al., 1977; KAVOUSSI; ROSS, 2007; MELZACK, 1976; MOON et al., 2007; OKADA; KAWAKITA, 2009; TAGUCHI, 2008; ZIJLSTRA et al., 2003). Acupuncture has been commonly used to treat acute and chronic pain (CAO, 2002; CASSU et al., 2008; FERRARI et al., 2006; HE, 1987; JOAQUIM et al., 2010; TAGUCHI, 2008).

To our knowledge, this is the first report investigating the use of $\mathrm{AqP}$ to prevent postoperative pain in dogs. The mechanical local effects produced by the injection of the saline solution might prolong the effect of acupuncture (LUNA et al., 2008; SOUSA et al., 2012).

The reduction in temperature is a typical finding during anaesthesia and was most likely produced by the combination of sedation, intravenous and inhalation anaesthesia, reduction of the metabolic rate and heat production, increased heat loss and central thermoregulation depression in hypothalamus (YOUNG; SLADEN, 1996). The 
reduction in temperature was more evident in animals of the $\mathrm{CG}$, as seven $(87.5 \%)$ animals from the CG in comparison to four (50\%) from the TG required the use of artificial warming to increase postoperative temperature. Although the differences were not significant, temperature was $0.6^{\circ} \mathrm{C}$ higher in animals submitted to AqP. Previous reports showed that according to thermography, both AP and EA analgesia reduces sympathetic vasomotor activity and increases superficial skin temperature (ERNST; LEE, 1985; LITSCHER et al., 2002; THOMAS et al., 1992).

The early use of morphine in the CG most likely contributed to the absence of differences in pain score evaluation between the groups at the time points that followed drug administration. Although the number of times rescue analgesia used was similar in both groups, none of the treatments were completely effective to prevent postoperative pain in bitches undergoing OHE. It is important to note that AqP provided sufficient postoperative analgesia in seven out $(87.5 \%)$ of eight animals for at least five hours: five hours in one (12.5\%) animal, eight hours in another $(12.5 \%)$ animal and 24 hours in five animals $(62.5 \%)$.

A previous study comparing nonsteroidal antiinflammatory drugs (NSAID), morphine and EA for postoperative analgesia, showed that NSAID provided a better analgesia than EA and morphine (BARROS, et al., 2006; PIGNATON et al., 2007) and EA was comparable to morphine in two studies using similar acupoints to those in our study (GAKIYA et al., 2011; PIGNATON et al., 2007). Otherwise dry needle acupuncture was as effective as meloxicam to treat postoperative pain using the same surgical protocol and species as reported here (FERRARI et al., 2006) and pharmacopuncture using $1 / 10$ of the dose of meloxicam was as effective as the conventional dose of meloxicam in cats undergoing $\mathrm{OHE}$, however 1/10 of the dose of meloxicam administered subcutaneously also showed similar results to acupuncture (PIGNATON et al., 2007).
In humans, EA reduced morphine consumption for 6-12 hours (SIM et al., 2002). Acupuncture and low and high frequency EA decreased the total amount of morphine by 21,43 and $61 \%$, respectively during the first postoperative 24 h following lower abdominal surgery (LIN et al., 2002) and AP reduced consumption of supplemental IV morphine by $50 \%$ for four days after lower and upper abdominal surgery (KOTANI et al., 2001). In the present study, $12.5 \%$ of the animals required morphine to complement analgesia, compared to $62.5 \%$ in the $\mathrm{CG}$, within 5 hours following surgery. These findings suggest a better preemptive analgesic effect of AqP when compared to morphine, as rescue analgesia was required in 50\% of the dogs after the first hour of OHE in a previous study (KONGARA et al., 2012).

It might be expected that neither morphine nor AqP would be completely effective in preventing postoperative pain in all dogs submitted to OHE (KONGARA et al., 2012). Surgical pain sensation and response to analgesic treatment vary according to each individual and are dependent of pharmacogenetics (HELLYER et al., 2007; LANDAU, 2006), even when identical stimuli are performed in similar environments (HANSEN, 2003).

Acupuncture analgesia embraces the majority of the pain mechanisms, like transduction, transmission, modulation and perception, involving an anti-inflammatory, humoral and neurological effect (CAO, 2002; HE, 1987; KAVOUSSI; ROSS, 2007; LIN; CHEN, 2008; MCLENNAN et al., 1977; MELZACK, 1976; MOON et al., 2007; OKADA; KAWAKITA, 2009; TAGUCHI, 2008; ZIJLSTRA et al., 2003). Both opioids and acupuncture activate inhibitory descending pathways in the spinal cord and prevent noxious stimuli to reach the brain (LIN; CHEN, 2008).

Some limitations may be credited to this study. Major differences among analgesic treatments could have been masked by the skilled surgeon and 
minimally invasive surgical technique. Sham AP was not used because it has been well addressed that the effect of AP performed in false points is inadequate when compared to AP performed in real points (CASSU et al., 2008).

To minimise type 2 error (i.e., failing to detect significant differences) and investigate duration and efficacy of rescue analgesia to treat pain, dogs treated with rescue analgesia were not excluded from the data. Otherwise type 1 error might be increased (i.e., increased possibility to observe significant differences between groups, when there was no real difference) and data would not be authentic if the pain score value was employed when rescue analgesia was administered.

The clinical relevance of this study is that AqP reduced the need for analgesic opiates in the postoperative period in dogs undergoing OHE, therefore, reducing the possible adverse effects of these drugs. Additionally, the advantage of AqP, when compared to dry needle AP, is that the injections may be performed quickly without maintaining the needles within the acupoints before surgery.

\section{Conclusions}

Acupoint injection at ST36, SP6, LIV3 and GB34 provided better analgesia than the $\mathrm{CG}$ for up to 5 hours after surgery and may be an option for post-operative analgesia in bitches undergoing OHE, providing that pain is assessed and rescue analgesia administered if necessary.

\section{Ethical Committee}

Approved by the Institutional Ethical Committee for the Use of Animals.

\section{Competing interests}

The authors declare that they have no competing interests'.

\section{Acknowledgements}

Authors are thankful for the financial support of Indian National Science Academy, New Delhi (India), Anand Agricultural University, Anand, Gujarat (India) and Brazilian Academy of Sciences, Rio de Janeiro, Brazil.

\section{References}

ALVARENGA, M. A.; FERREIRA, J. P. C., MEIRA, C., LUNA, S. P. L.; BURNS, P. J. Induction of luteolysis in mares utilizing a micro-dose of prostaglandin F2 $\alpha$ in the sacral lumbar space. Journal of Equine Veterinary Science (Print), Amsterdan, v. 18, n. 3, p.167-168, 1998.

BARROS, M.; LUNA, S.; SZABO, M. Pre-treatment with electroacupuncture, morphine and carprofen for postoperative analgesia in ovariohysterectomy in dogs. In: INTERNATIONAL CONGRESS ON VETERINARY ACUPUNCTURE, 32., 2006, Boston. Proceedings... Red Hook: Curran \& Associates, 2006. p. 32.

CAO, X. Scientific bases of acupuncture analgesia. Acupuncture \& Electro-Therapeutics Research, New York, v. 27, n. 1, p. 1-14, 2002.

CASSU, R. N.; LUNA, S. P. L.; CLARK, R. M. O.; KRONKA, S. N. Electroacupuncture analgesia in dogs: is there a difference between uni- and bi-lateral stimulation? Veterinary Anaesthesia and Analgesia, Oxford, v. 35, n. 1, p. 52-61, jan. 2008.

CHERNYAK, G. V.; SESSLER, D. I. Perioperative acupuncture and related techniques. Anesthesiology, Philadelphia, v. 102, n. 5, p. 1031-1049, 2005.

CLARK, J. S. Evaluation of topical nalbuphine or oral tramadol as analgesics for corneal pain in dogs: a pilot study. Veterinary Ophthalmology, England, v. 14, n. 6, p. 358-364, 2011.

DI MARTINO, I.; LUNA, S. Non-conventional treatment options for surgical and postoperative analgesia in dogs. In: NAPLES PAIN CONFERENCE, 2010, Naples, Proceedings... Naples: Accademia Pontaniana, 2010. p. 76-78.

ERNST, M.; LEE, M. H. M. Sympathetic vasomotor changes induced by manual and electrical acupuncture of the hoku point visualized by thermography. Pain, New York, v. 21, n. 1, p. 25-33, 1985.

FERRARI, D.; LUNA, S. P. L.; LIMA, A. F.; MARUCIO, R.; PAPAROTTO, T.; TAKAHIRA, R.; VESCE, G. Effetti analgesici ed emostatici perioperatori dell'agopuntura in cagne sottoposte ad ovarioisterectmia. 
Obiettivi \& Documenti Veterinari, Bologna, v. 27, n. 9, p. 11-20, 2006.

FIRTH, A. M.; HALDANE, S. L. Development of a scale to evaluate postoperative pain in dogs. Journal of the American Veterinary Medical Association, New York, v. 214, n. 5, p. 651-659, mar. 1999.

FOX, S. M.; MELLOR, D. J.; STAFFORD, K. J.; LOWOKO, C. R.; HODGE, H. The effects of ovariohysterectomy plus different combinations of halothane anaesthesia and butorphanol analgesia on behaviour in the bitch. Research in Veterinary Science, New York, v. 68, n. 3, p. 265-274, jun. 2000.

GAKIYA, H. H.; SILVA, D. A.; GOMES, J.; STEVANIN, H.; CASSU, R. N. Electroacupuncture versus morphine for the postoperative control pain in dogs. Acta Cirurgica Brasileira, São Paulo, v. 26, n. 5, p. 346-351, oct. 2011.

GROPPETTI, D.; PECILE, A. M.; SACERDOTE, P.; BRONZO, V.; RAVASIO, G. Effectiveness of electroacupuncture analgesia compared with opioid administration. British Journal of Anaesthesia, Oxford, v. 107, n. 4, p. 612-618, oct. 2011.

HABACHER, G.; PITTLER, M. H.; ERNST, E. Effectiveness of Acupuncture in veterinary medicine: systematic review. Journal of Veterinary Internal Medicine, Southern Gate, v. 20, n. 3, p. 480-488, 2006.

HANSEN, B. D. Assessment of pain in dogs: veterinary clinical studies. Ilar Journal, Oxford, v. 44, n. 3, p. 197205, 2003.

HARDIE, E. M. Assessing pain in animals. Journal of the American Veterinary Medical Association, New York, v. 211, n. 8, p. 977-978, oct. 1997.

HE, L. F. Involvement of endogenous opioid peptides in acupuncture analgesia. Pain, New York, v. 31, n. 1, p. 99-121, oct.1987.

HELLYER, P.; RODAN, I.; BRUNT, J.; DOWNING, R.; HAGEDORN, J. E.; ROBERTSON, S. A. AAHA/AAFP pain management guidelines for dogs \& cats. Journal of the American Animal Hospital Association, Colorado, v. 43, n. 5, p. 235-248, sept./oct. 2007.

JOAQUIM, J.; MORAIS, R.; MIRANDA, J. R. A.; LUNA, S. P. L. Effect of acupuncture/electroacupuncture on gastric pressure and contraction of dogs measured by alternate current susceptometry and manometry. Ars Veterinaria, Jaboticabal, v. 24, n. 1, p. 9-14, 2008.

JOAQUIM, J. G.; LUNA, S. P.; BRONDANI, J. T.; TORELLI, S. R.; RAHAL, S. C.; FREITAS, F. P. Comparison of decompressive surgery, electroacupuncture, and decompressive surgery followed by electroacupuncture for the treatment of dogs with intervertebral disk disease with long-standing severe neurologic deficits. Journal of the American Veterinary Medical Association, New York, v. 236, n. 11, p. 12251229, jun. 2010.

KAVOUSSI, B.; ROSS, B. E. The neuroimmune basis of anti-inflammatory acupuncture. Integrative Cancer Therapies, Chicago, v. 6, n. 3, p. 251-257, sept. 2007.

KLIDE, A.; GAYNOR, J. Acupuncture for surgical analgesia and postoperative analgesia. In: AM, S. (Ed.). Veterinary acupuncture. Ancient art to modern medicine. $2^{\text {nd }}$ ed. St Louis: Mosby, 2001. p. 295-302.

KONGARA, K.; CHAMBERS, J. P.; JOHNSON, C. B. Effects of tramadol, morphine or their combination in dogs undergoing ovariohysterectomy on peri-operative electroencephalographic responses and post-operative pain. New Zealand Veterinary Journal, Palmerston North, v. 60, n. 2, p. 129-135, mar. 2012.

KOTANI, N.; HASHIMOTO, H.; SATO, Y.; SESSLER, D. I.; YOSHIOKA, H.; KITAYAMA, M.; YASUDA, T.; MATSUKI, A. Preoperative intradermal acupuncture reduces postoperative pain, nausea and vomiting, analgesic requirement, and sympathoadrenal responses. Anesthesiology, Philadelphia, v. 95, n. 2, 2001.

LANDAU, R. One size does not fit all: genetic variability of mu-opioid receptor and postoperative morphine consumption. Anesthesiology, Philadelphia, v. 105, n. 2, p. 235-237, aug. 2006.

LIN, J. G.; CHEN, W. L. Acupuncture analgesia: a review of its mechanisms of actions. The American Journal of Chinese Medicine, New Jersey, v. 36, n. 4, p. 635-645, 2008.

LIN, J. G.; LO, M. W.;WEN, Y. R.; HSIEH, C. L.; TSAI, S. K.; SUN, W. Z. The effect of high and low frequency electroacupuncture in pain after lower abdominal surgery. Pain, New York, v. 99, n. 3, p. 509-514, oct. 2002.

LITSCHER, G.;WANG, L.; HUBER, E.; NILSSON, G. Changed skin blood perfusion in the fingertip following acupuncture needle introduction as evaluated by laser doppler perfusion imaging. Lasers in Medical Science, London, v. 17, n. 1, p. 19-25, jan. 2002.

LOPES, M. D.; LUNA, S. P. L.; ALVARENGA, F. L.; LEAL, A. C. R. Clinical and neurological signs of newborn dogs after cesarean section using inhalation anesthesia or electroacupuncture. In: ANN INTERNATIONAL CONGRESS ON VETERINARY ACUPUNTURE, 24., 1998, Chitou. Proceedings... Red Hook: Curran \& Associates, 1998. p. 132-133. 
LUNA, S. Acupuncture studies performed in Brazil. In: IVAS WORLD CONGRESS ON VETERINARY ACUPUNTURE \& RELATED TECHNIQUES, 26., 2000, Vienna. Proceedings... Red Hook: Curran \& Associates, 2000. p. 175-182.

Emprego da acupuntura em anestesia. In: FANTONI, D.; CORTOPASSI, S. (Ed.). Anestesia em cães e gatos. São Paulo: Roca, 2002. p. 337-343.

LUNA, S. P.; ANGELI, A. L.; FERREIRA, C. L.; LETTRY, V.; SCOGNAMILLO-SZABÓ, M. Comparison of pharmacopuncture, aquapuncture and acepromazine for sedation of horses. Evidence-Based Complementary and Alternative Medicine, New York, v. 5, n. 3, p. 267272, sept. 2008.

LUNA, S.; TAYLOR, P. Effect of electroacupuncture on endogenous opioids, AVP, ACTH, Cortisol and catecholamine concentrations measures in the cerebroespinal fluid (CSF), Peripheral and pituitary effluente plasma of ponies. In: ANN INTERNATIONAL CONGRESS ON VETERINARY ACUPUNTURE, 24., 1998, Chitou. Proceedings... Red Hook: Curran \& Associates, 1998. p. 172-174.

MATHEWS, K. A. Pain assessment and general approach to management. Veterinary Clinics of North America: Small Animal Practice, Philadelphia, v. 30, n. 4, p. 729755, jul. 2000.

MCLENNAN, H.; GILFILLAN, K.; HEAP, Y. Some pharmacological observations on the analgesia induced by acupuncture in rabbits. Pain, New York, v. 3, n. 3, p. 229-238, jun. 1977.

MELZACK, R. Acupuncture and pain mechanisms (author's transl). Anaesthesist, Berlin, v. 25, n. 5, p. 204207, may 1976.

MOON, P. D.; JEONG, H. J.; KIM, S. J.; AN, H. J.; LEE, H. J.; YANG, W. M.; PARK, S. K.; HONG, S. H.; KIM, H. M.; UM, J. Y. Use of electroacupuncture at ST36 to inhibit anaphylactic and inflammatory reaction in mice. Neuroimmunomodulation, Basel, v. 14, n. 1, p. 24-31, 2007.

O'BOYLE, M. A.; VAJDA, G. K. Acupuncture anesthesia for abdominal surgery. Modern Veterinary Practice, v. 56, n. 10, p. 705-707, 1975.

OKADA, K.; KAWAKITA, K. Analgesic action of acupuncture and moxibustion: a review of unique approaches in Japan. Evidence-Based Complementary and Alternative Medicine, New York, v. 6, n. 1, p. 11-17, 2009.

OLIVEIRA, R.; PRADO, W. A. Anti-hyperalgesic effect of electroacupuncture in a model of post-incisional pain in rats. Brazilian Journal of Medical and Biological Research, São Paulo, v. 33, n. 8, p. 957-960, 2000.
PIBAROT, P.; DUPUIS, J.; GRISNEAUX, E.; CUVELLIEZ, S.; PLANTÉ, J.; BEAUREGARD, G.; BONNEAU, N. H.; BOUFFARD, J.; BLAIS, D. Comparison of ketoprofen, oxymorphone hydrochloride, and butorphanol in the treatment of postoperative pain in dogs. Journal of the American Veterinary Medical Association, New York, v. 211, n. 4, p. 438-444, aug. 1997.

PIGNATON, W.; SIMÕES, J. R.; ZACCHÉ, E.; FREITAS, P. M. C.; LUZ, M. R.; MELO, M. S.; BAUNGARTEN, L. B. Effect of electroacupuncture and morphine on cardiorespiratory parameters and anesthetic consumption in cats undergoing ovariohysterectomy. Acta Scientiae Veterinariae, Porto Alegre, v. 35, n. 2, p. 331-332, 2007.

SHIH, A. C.; ROBERTSON, S.; ISAZA, N.; PABLO, L.; DAVIES, W. Comparison between analgesic effects of buprenorphine, carprofen, and buprenorphine with carprofen for canine ovariohysterectomy. Veterinary anaesthesia and analgesia, Oxford, v. 35, n. 1, p. 69-79, jan. 2008.

SIM, C. K.; XU, P. C.; PUA, H. L.; ZHANG, G.; LEE, T. L. Effects of electroacupuncture on intraoperative and postoperative analgesic requirement. Acupuncture in Medicine, United Kingdom, v. 20, n. 2-3, p. 56-65, aug. 2002.

SKARDA, R. T.; MUIR, W. W. Comparison of electroacupuncture and butorphanol on respiratory and cardiovascular effects and rectal pain threshold after controlled rectal distention in mares. American Journal of Veterinary Research, New York, v. 64, n. 2, p. 137144, feb. 2003.

SOUSA, N. R. D.; LUNA, S. P. L.; CÁPUA, M. L. B.; LIMA, A. F. M.; OLIVEIRA, F. A.; VIVEIROS, B. M.; BARBOSA, L. Analgesia da farmacopuntura com meloxicam ou da aquapuntura preemptivas em gatas submetidas à ovariosalpingohisterectomia. Ciência Rural, Santa Maria, v. 42, n. 7, p. 1231-1236, 2012.

STILL, J. Acupuncture analgesia for laparotomy in dogs and cats: an experimental study. American Journal of Acupuncture, Capitola, v. 15, p. 155-165, 1987.

SUN, Y.; GAN, T. J.; DUBOSE, J. W.; HABIB, A. S. Acupuncture and related techniques for postoperative pain: a systematic review of randomized controlled trials. British Journal of Anaesthesia, London, v. 101, n. 2, p. 151-60, aug. 2008.

TAFFAREL, M. O.; SALGADO, A. E. P.; MELO FILHO, E. V.; TEIXEIRA, L. R.; FRACALOSSI, L. D. C.; LUZ, M. R.; FREITAS, P. M. C. Efeitos da eletroacupuntura, aquapuntura e farmacopuntura em cadelas anestesiadas 
com isofluorano e submetidas à ovário-histerectomia. Arquivo Brasileiro de Medicina Veterinária e Zootecnia, Belo Horizonte, v. 64, n. 1, p. 23-31, 2012.

TAGUCHI, R. Acupuncture anesthesia and analgesia for clinical acute pain in Japan. Evidence-Based Complementary and Alternative Medicine, New York, v. 5, n. 2, p. 153-158, jun. 2008.

TEIXEIRA, L. R.; LUNA, S. P.; TAFFAREL, M. O.; LIMA, A. F.; SOUSA, N. R.; JOAQUIM, J.G.; FREITAS, P. M. Comparison of intrarectal ozone, ozone administered in acupoints and meloxicam for postoperative analgesia in bitches undergoing ovariohysterectomy. The Veterinary Journal, New York, v. 197, n. 3, p. 794-799, sept. 2013.

THOMAS, D.; COLLINS, S.; STRAUSS, S. Somatic sympathetic vasomotor changes documented by medical thermographic imaging during acupuncture analgesia. Clinical Rheumatology, United Kingdom, v. 11, n. 1, p. 55-59, mar. 1992.
TSENG,C.K.; TAY,A.A.; PACE, N.L.; WESTENSKOW, D. R.; WONG, K. C. Electro-acupuncture modification of halothane anaesthesia in the dog. Canadian Anaesthetists' Society Journal, Toronto, v. 28, n. 2, p. 125-128, mar. 1981.

WRIGHT, M.; MCGRATH, C. J. Physiologic and analgesic effects of acupuncture in the dog. Journal of the American Veterinary Medical Association, New York, v. 178, n. 5, p. 502-507, mar. 1981.

XIE, H.; VANESSA, P. The meridians. In: XIE, H.; VANESSA, P. (Ed.). Traditional chinese veterinary medicine. Beijing: Jing Tang, 2002. v. 1, p. 149-205.

YOUNG, C. C.; SLADEN, R. N. Temperature monitoring. International Anesthesiology Clinics, Boston, v. 34, n. 3, p. 149-174, 1996.

ZIJLSTRA, F. J.; LANGE, I. V. D. B.; HUYGEN, F. J. P. M.; KLEIN, J. Anti-inflammatory actions of acupuncture. Mediators of Inflammation, New York, v. 12, n. 2, p. 5969, apr. 2003. 
